\title{
The reasons and adverse effect of internal diesel injector deposits formation
}

\begin{abstract}
The paper report on the state of affairs so far in the scope of internal diesel injection deposits (IDID) issue affecting modern diesel high pressure common rail (HPCR) systems. Different types of deposits have been described and the factors supporting their creation. These deposits have been extensively studied to understand their formation mechanisms and composition. To this end an engine test procedure was developed to assess the deposit forming tendencies of various types. Findings of two long time dynamometer engine tests in which the course of the IDID formation and HPCR performance impairing was followed by measurement different engine parameters have been reported. Performance evaluation of HPCR injectors before and after tests have been presented also.
\end{abstract}

Key words: IDID injectors deposits type, HPCR engine fuel injection systems, Diesel engines

\section{Przyczyny powstawania i szkodliwy wpływ wewnętrznych osadów we wtryskiwaczach silników o zapłonie samoczynnym}

\begin{abstract}
W artykule omówiono potencjalne przyczyny i skutki tworzenia się wewnętrznych osadów (IDID - Internal Diesel Injector Deposits w wysokociśnieniowych układach wtrysku paliwa typu HPCR (High Pressure Common Rail) silników o zapłonie samoczynnym. Opisano różne typy takich osadów oraz czynniki powodujące ich powstawanie. Przeprowadzono symulowane testy silnikowe, wg własnej metodyki badawczej, w których wytworzono przedmiotowe osady dwóch typów o różnym składzie i charakterze. Przedstawiono wyniki dwóch dlugotrwatych testów silnikowych, w których obserwowano przebieg powstawania IDID (i zwiazane z tym pogarszanie właściwości użytkowych układu HPCR) poprzez monitorowanie różnych parametrów diagnostycznych silnika, a następnie ocenę wtryskiwaczy po testach.
\end{abstract}

Słowa kluczowe: osady typu IDID, układy wtryskowe typu HPCR, silniki o zapłonie samoczynnym

\section{Introduction}

Expansion of diesel engines with direct fuel injection in the late 90's of the last century brought about rapid development in high-pressure injection systems out of which in the following years the largest popularity has achieved the system of HPCR type (High Pressure Common Rail). In case of those systems, similarly to earlier types of fuel injection systems, appeared the problem of external coke deposits accumulating in the ducts and around outlet holes of multihole nozzles. And while in diesel engines with indirect fuel injection the amount and rate of coke formation were widely influenced by the type of injector used, in case of direct fuel injection it is the fuel that plays the key role in formation of the subject coke deposits.

At the same time, since about 2008, there has been observed an alarmingly increasing number of failures of HPCR systems and in consequence failures of engines, induced by formation of deposits on working components of internal subassemblies of the systems, and on injectors in particular. Conducted chemical analysis proved the deposits to be of different composition and morphology from external coke deposits in ducts and around the outlet holes of the multi-hole nozzles analyzed up to now [1-4]. It was also found that the factors causing formation of this new group of deposits, called internal diesel injector deposits (IDID), and conditions promoting their growth are utterly different from those influencing formation of external coke deposits - see Fig. 1.

In currently used systems of HPCR type, injection pressure amounts to 2000 or even up to 2200 bar and the quantity

\section{Wstęp}

Rozpowszechnienie, w drugiej połowie lat 90. ubiegłego wieku, silników o zapłonie samoczynnym z bezpośrednim wtryskiem paliwa spowodowało gwałtowny rozwój wysokociśnieniowych układów wtrysku paliwa, spośród których, w kolejnych latach, największą popularność zyskał układ typu HPCR (High Pressure Common Rail). Jednak dla tych układów, podobnie jak we wcześniejszych typach układów wtrysku paliwa, pojawił się problem zewnętrznych osadów koksowych gromadzących się w kanalikach i wokół otworków wylotowych wielootworkowych rozpylaczy. Przy czym, o ile w silnikach ZS z pośrednim wtryskiem paliwa na wielkość i szybkość zakoksowania rozpylaczy wtryskiwaczy duży wpływ ma typ zastosowanego rozpylacza, o tyle dla silników z bezpośrednim wtryskiem paliwa właśnie paliwo odgrywa kluczową rolę w tworzeniu przedmiotowych osadów koksowych.

Równocześnie, od około 2008 r., zaczęto obserwować na całym świecie niepokojąco zwiększającą się liczby awarii układów HPCR, a w konsekwencji silników, związanych z powstawaniem osadów na wewnętrznych elementach roboczych podzespołów przedmiotowych układów, a w szczególności wtryskiwaczy. Przeprowadzone analizy chemiczne wykazały, że osady te mają odmienny skład i morfologię od dotychczas badanych, zewnętrznych osadów koksowych w kanalikach i wokół otworków wylotowych rozpylaczy [1-4]. Stwierdzono też, że czynniki powodujące powstawanie tej nowej grupy osadów, nazwanych osadami wewnętrznymi układów wtryskowych silników ZS (IDID - 
of fuel dosed and injected through holes of diameter frequently less than $100 \mu \mathrm{m}$, for cars with engine cubic capacity of about 21 , ranges from $1 \mathrm{~mm}^{3}$ (initial dose - guiding) to $40 \mathrm{~mm}^{3}$ (dose at full engine load). Simultaneously, the injection time of the subject fuel dose is $1-2$ milliseconds, which in case of multiple injection (multiphase) strategy means 10000 injections per minute [4]. The fastest currently used electromagnetic injectors obtain the opening time of 0.303 $\mathrm{ms}$, and in case of more and more widely used piezoelectric injectors it is up to $0.1 \mathrm{~ms}$. Considering the above operating parameters of injectors and required very high precision of their manufacturing (clearance between the casing of the nozzle and cylindrical needle moving within the casing is about $1 \mu \mathrm{m}$ ) associated with very high pressures of fuel injecting, any internal deposits on surfaces of cooperating internal elements have adverse influence on functioning of the whole assembly. Nozzles must provide appropriate timing of opening and sufficient time of injection into combustion chambers. When closed, any leak is unacceptable as this could adversely influence emission of harmful components from engine, lead to higher fuel consumption and to coke formation and distortion of the flow of fuel streams from holes and their tips, which would impair the fuel injection process in terms of quantity and quality. IDID slow down the injectors' operating rate (so called shifting time) and glue (immobilize) the cooperating components of injectors leading to loss of control not only in terms of quantity and quality of formed fuel dose but also in terms of its distribution during

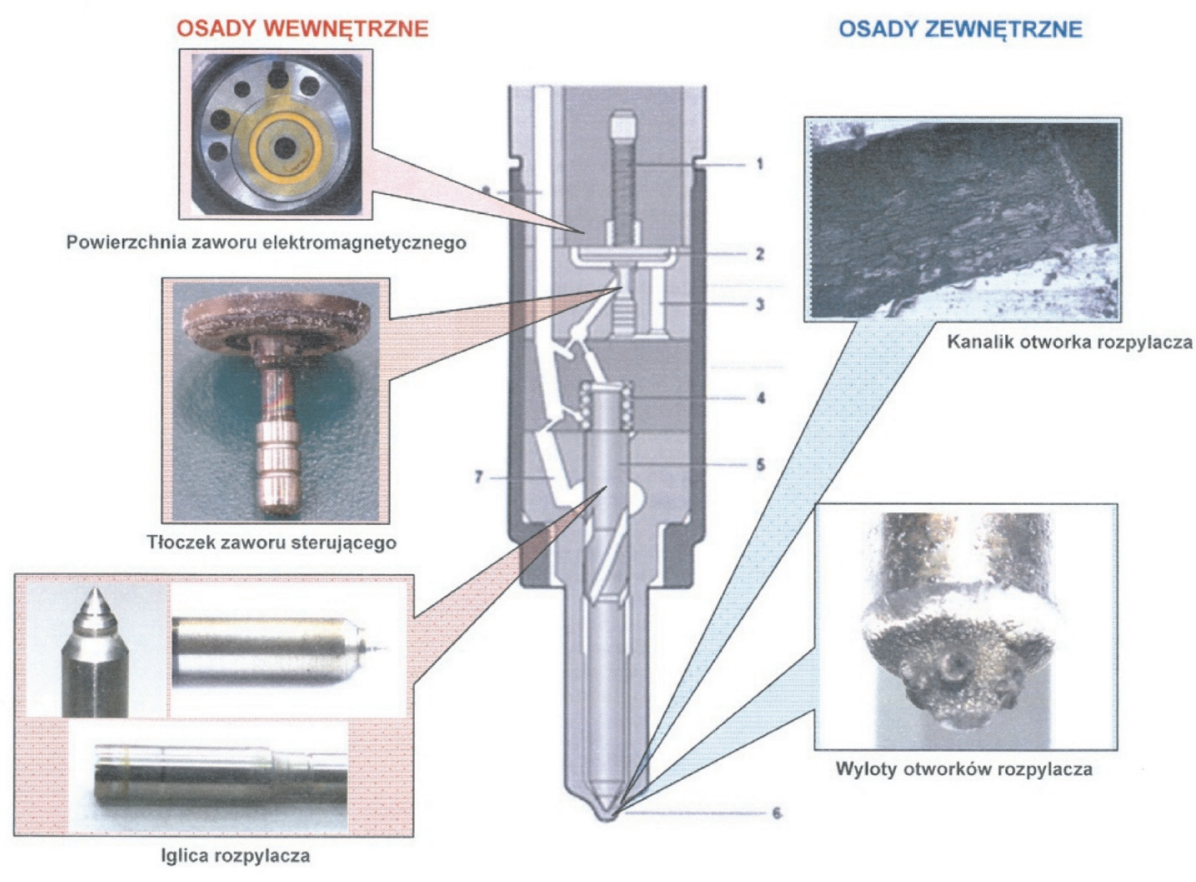

Fig. 1. Sectional view of fuel injection system of HPCR type with marked areas where internal and external deposits occur: 1 - spring of electromagnetic valve, 2 - control valve, 3 - outflow fuel drain, 4 - fuel distribution control chamber, 5 - nozzle needle, 6 - nozzle hole, 7 - initial chamber

Rys. 1. Przekrój wtryskiwacza układu wtrysku paliwa typu HPCR z zaznaczonymi obszarami występowania osadów wewnętrznych i zewnętrznych: 1 - sprężyna zaworu elektromagnetycznego, 2 - zawór sterujący,

3 - kanal odplywowy paliwa, 4-komora sterująca rozdziałem paliwa, 5 - iglica rozpylacza, 6 - otworek rozpylacza, 7 - komora wstęna
Internal Diesel Injector Deposit) i warunki sprzyjające ich przyrostowi są zupełnie inne niż dla zewnętrznych osadów koksowych - rys. 1.

W obecnie stosowanych układach typu HPCR ciśnienie wtrysku paliwa sięga 2000, a nawet 2200 bar, a ilość odmierzanego, a następnie wtryskiwanego, przez otworki o średnicy często poniżej $100 \mu \mathrm{m}$, paliwa dla silnika do samochodu osobowego o pojemności skokowej ok. 2 litrów, zawiera się w zakresie od $1 \mathrm{~mm}^{3}$ (dawka wstępna - pilotująca) do $40 \mathrm{~mm} 3$ (dawka przy pełnym obciążeniu silnika). Czas wtrysku dawki paliwa to 1-2 milisekundy, co w odniesieniu do strategii wtrysku wielokrotnego (wielofazowego) oznacza wykonanie do 10000 wtrysków na minutę [4]. Najszybsze stosowane obecnie wtryskiwacze elektromagnetyczne uzyskują czas otwarcia równy $0,303 \mathrm{~ms}$, a coraz szerzej wykorzystywane wtryskiwacze piezoelektryczne - do 0,1 ms. Biorąc pod uwagę powyższe parametry użytkowe wtryskiwaczy i wymaganą ich bardzo dużą dokładność wykonania (luz pomiędzy obudową rozpylacza i poruszającą się w nim walcową, prowadzącą częścią iglicy wynosi około $1 \mu \mathrm{m}$ ), azana z bardzo wysokimi ciśnieniami wtrysku paliwa, osady wewnętrzne na powierzchniach współpracujących elementów roboczych mają szkodliwy wpływ na działanie całego zespołu. Rozpylacze muszą gwarantować odpowiednią chwilę otwierania i czas trwania wtrysku paliwa komór spalania. W stanie zamkniętym nie mogą wykazywać przecieków, które mogłyby niekorzystnie wpływać na emisję szkodliwych składników spalin z silnika, zwiększenie zużycia paliwa i prowadzić do zakoksowania i zniekształcenia wypływu strug paliwa z otworów ich końcówek, co zaburzałoby w sposób ilościowy i jakościowy proces rozpylania paliwa. IDID spowalniają szybkość działania wtryskiwaczy (tzw. czas przesterowania) i sklejają (unieruchamiają) współpracujące ze sobą elementy robocze wtryskiwaczy, co prowadzi do utraty kontroli nie tylko w zakresie ilościowego i jakościowego tworzenia dawki paliwa, ale także jej podziału podczas wtrysku wielofazowego i okresu wtryskiwania w czasie. IDID wpływają też na niekontrolowane zaburzenia profilu zmian ciśnienia wielofazowego wtrysku paliwa przez osadzanie się na zworach i kotwicach elektromagnesów sterujących przepływem paliwa we wtryskiwaczach. W praktyce powoduje to: utrudniony rozruch silnika, wypadanie zapłonów, nierównomierną pracę silnika zarówno na biegu jałowym, jak i podczas 
multiphase injection and over the injection period. IDID, due to depositing on valves and anchors of electromagnets controlling fuel flow in injectors, also cause uncontrolled disturbances in the profile of pressure changes in multiphase fuel injection. In practice it causes difficulties in starting the engine, misfiring, uneven operation of engine both in idle run and under load, uncontrolled changes of engine power and torque, increase in emission of harmful components and opacity of exhaust fumes, higher fuel consumption and $\mathrm{CO}_{2}$ emission. Therefore, the main threats of IDID formation for correct operation of HPCR system arises from reduced operating dynamic of internal working components of injectors or from their sticking together which results in hydraulic dysfunction of those vital subassemblies. Additional factor promoting IDID formation in injection system of HPCR type is high working temperature accelerating oxidation and decomposition of chemically unstable fuel components.

\section{Types of internal injector deposits (IDID)}

Tests of IDID conducted so far allow us to assume a few hypothetical mechanisms of IDID formation, however each of those mechanisms requires further tests for verification and/or final confirmation. It ensues from complexity of factors and conditions potentially influencing initialisation and formation of the subject deposits, the most important of which are: fuel composition and its treated additives, amount of different impurities entering fuel at the stage of production and transport (even in quantities below $1 \mathrm{mg} / \mathrm{kg}$ ), amount and quality of FAME in fuel, engine operating conditions, temperatures achieved by fuel in fuel injection system, etc. Moreover, the physical character of deposits may differ as those might be soaps and metal salts or ashless materials such as imide or amide organic polymers $[1,5,11]$. Also the boundary conditions in which IDID form are not known.

Modern fuel injection systems are lubricated by fuel flowing through. Diesel oils manufactured nowadays contain various acid components. Fatty acids of different saturation levels are commonly used as lubricating additives. As it was proved, such acids easily react with metal ion impurities in fuel, forming soaps and deposits. For example, fatty acid soaps containing zinc cause settling of coke deposits on outlet holes of injector nozzle. It has been known for some time already that carboxylate salts and polar chemical compounds with low molecular weight are less soluble in low-sulphur diesel fuels than in previously used high-sulphur diesel fuels. That, combined with conditions inside injectors in HPCR systems, promotes formation of internal deposits. For example, sodium soaps of fatty acids are slightly soluble in diesel fuel thus they can foster tendencies for formation of internal deposits inside injectors. Growing share of FAME in diesel oils results in increase of sodium content in fuel, as this metal is present in typical catalysts used in transesterification reactions. Sodium ions captured by fatty acids being by-product of FAME or used as lubricating additives generate deposits of sodium soaps which, due to weak solubility in fuel, precipitate in the form of IDID. FAME contained in diesel oil might additionally promote jego obciążania, niekontrolowane zmiany mocy i momentu obrotowego silnika, wzrost zadymienia i emisji szkodliwych składników w spalinach silnika, wzrost zużycia paliwa i emisji $\mathrm{CO}_{2}$. Zatem zagrożenia związane z powstawaniem IDID dla poprawnej pracy układu HPCR wynikają z ograniczania dynamiki pracy wewnętrznych elementów roboczych wtryskiwaczy lub ich całkowitego sklejania, co powoduje hydrauliczną dysfunkcję działania tych ważnych podzespołów. Dodatkowym czynnikiem sprzyjającym powstawaniu IDID w układach wtrysku paliwa typu HPCR jest wysoka temperatura ich pracy, a to przyspiesza utlenianie i dekompozycję chemicznie niestabilnych składników paliwa.

\section{Typy wewnętrznych osadów wtryskiwaczy (IDID)}

Dotychczas przeprowadzone badania IDID pozwolity hipotetycznie założyć kilka mechanizmów ich tworzenia, jednak każdy z tych mechanizmów wymaga prowadzenia dalszych badań w celu ich zweryfikowania i/lub ostatecznego potwierdzenia. Bierze się to z dużej złożoności czynników i warunków mogących mieć wpływ na inicjowanie powstawania, a następnie na tworzenie się przedmiotowych osadów, z których najważniejsze to: skład paliwa i uszlachetniających go dodatków, ale także zawartość różnych zanieczyszczeń przedostających się zarówno podczas produkcji paliw, jak i ich transportu (nawet w ilościach poniżej $1 \mathrm{mg} / \mathrm{kg}$ ), ilość i jakość zawartego w paliwie FAME, warunki pracy silnika, temperatury, do jakich nagrzewa się paliwo w układzie wtrysku paliwa itp. Ponadto, charakter fizyczny przedmiotowych osadów może być różny, jako że mogą to być mydła i sole metali, lub bezpopiołowe materiały w postaci imidowych lub amidowych polimerów organicznych. [1, 5, 11]. Dodatkowo nie są znane graniczne warunki, w jakich mogą powstawać IDID.

We współczesnych układach wtrysku paliwa do ich smarowania wykorzystywane jest przepływające przezeń paliwo. Obecnie wytwarzane oleje napędowe zawierają rozmaite komponenty kwasowe. W różnym stopniu nienasycone kwasy thuszczowe są powszechnie używane jako dodatki smarnościowe. Jak wykazano, takie kwasy łatwo reagują z jonami metali, stanowiącymi zanieczyszczenia paliwa, formując mydła i osady. Przykładowo, mydła kwasów tłuszczowych zawierające cynk powodują odkładanie się osadów zakoksowujących otwory wylotowe rozpylaczy wtryskiwaczy. Od dhuższego czasu wiadomo, że sole karboksylowe i polarne związki o małej masie cząsteczkowej słabiej rozpuszczają się w niskosiarkowych olejach napędowych, aniżeli w dawniej stosowanych, wysokosiarkowych. To w połączeniu z warunkami panującymi wewnątrz wtryskiwaczy układów HPCR sprzyja tworzeniu osadów wewnętrznych. Dla przykładu, sodowe mydła kwasów tłuszczowych są słabo rozpuszczalne w oleju napędowym, a zatem mogą wzmagać tendencje do tworzenia wewnętrznych osadów we wtryskiwaczach.

Coraz większy udział FAME w olejach napędowych wpływa na wzrost zawartości sodu $\mathrm{w}$ paliwie, ponieważ metal ten jest składnikiem typowych katalizatorów stosowanych $\mathrm{w}$ reakcjach transestryfikacji. Jony sodu prze- 
formation of deposits of IDID type due to content of acid impurities generated during production of FAME and formed in the process of autocatalyctic decomposition of fatty esters with metal ions involved [6]. Thus generated deposits may result in sticking together the surfaces of cooperating moving parts [1-5] and strengthen corrosion processes. In the USA, Denmark and France it has been observed that sodium salts, typically in form of nitrites $\left(\mathrm{NaNO}_{2}\right)$, used as corrosion inhibitors in fuel industry pipelines at only $>0.1 \mathrm{mg} / \mathrm{kg}$ content may react with fatty acids included in lubricating additives, resulting in formation of sodium salts of fatty acids [5]. Being slightly soluble in diesel fuel, they easily separate from fuel and adhere on internal surfaces of working elements of subassemblies of fuel injection system in form of light grey substance.

In European countries more frequently are observed IDID formed from organic polymers. Such deposits form viscous, brown wax covering internal surfaces of elements of HPCR systems and their chemical composition essentially differs from the above-described soaps with metal ions. The latter do not contain metal ions. They results from reaction of commonly used detergent additives for diesel fuels in form of polyisobutylene succinimide (PIBSI) counteracting formation of external coke deposits, with formic acid, corrosion inhibitors and lubricating additives in form of fatty acids monomers or dimers. Exceptionally susceptible to subject deposits formation are PIBSIs with high content of primary amine in interaction with carboxylate dimmers of fatty acids. Generated deposits are insoluble in commonly used organic solvents, which significantly hinder their analysis and defining chemical structure.

Tests conducted so far indicate also possibility of IDID formation from products of fuel oxidation. Such products may be present particularly in case of unstable diesel fuels containing FAME or originate from deterioration of fatty acids esters included in lubricating additives $[1-5,7-9,11]$.

Summarising, the above-described IDID, present in fuel injection systems of HPCR type might be divided into three groups:

Type I - defined as: soaps including metal ions (mostly sodium soaps of fatty acids) or "waxy" deposits or carboxylate soaps or carboxylate salts. They are formed as a result of interaction of:

- corrosion inhibitors with fatty acid monomers used in lubricating additives,

- corrosion inhibitors with fatty acid dimers used in lubricating additives,

- corrosion inhibitors with alkenyl-succinic acids such as DDS (dodecenyl succinic acid) and HDS (hexadecenyl succinic acid) used in lubricating additives.

Type II - defined as: viscous, waxy deposits or organic polymer deposits or amide deposits. They are formed as a result of interaction of:

- detergent additives such as polyisobutylene succinimide (PIBSI) with formic acid,

- detergent additives such as polyisobutylene succinimide (PIBSI) with fatty acid used in lubricating additives (particularly with fatty acid dimmers) chwytywane przez kwasy thuszczowe będące produktami ubocznymi FAME lub stosowane jako dodatki smarnościowe generują osady typu mydeł sodu, które na skutek słabej rozpuszczalności w paliwie wytrącają się w postaci IDID. Zawarte w oleju napędowym FAME mogą dodatkowo sprzyjać tworzeniu osadów typu IDID przez zawarte w nich kwasowe zanieczyszczenia powstałe podczas produkcji FAME oraz te uformowane przez autokatalityczny podział estrów thuszczowych z udziałem jonów metali [6]. Powstałe w ten sposób osady mogą powodować sklejanie powierzchni ruchowo współpracujących ze sobą elementów [1-5] i intensyfikować procesy korozyjne. W USA, Danii i Francji zaobserwowano, że sole sodowe, zazwyczaj w postaci azotynów $\left(\mathrm{NaNO}_{2}\right)$, używane jako inhibitory korozji w rurociągach do przesyłu paliw, już przy zawartości $>0,1 \mathrm{mg} / \mathrm{kg}$ w paliwie mogą wchodzić w reakcje z kwasami thuszczowymi, stanowiącymi dodatki smarnościowe, tworząc sodowe mydła kwasów tłuszczowych [5]. Jako słabo rozpuszczalne w oleju napędowym, łatwo rozdzielają się z nim i przywierają do wewnętrznych powierzchni elementów roboczych podzespołów układu wtrysku paliwa w postaci osadów o jasnej biało-szarej barwie.

W krajach Europejskich częściej obserwowane są IDID tworzone z polimerów organicznych. Osady te mają postać lepkich, brązowych laków pokrywających wewnętrzne powierzchnie elementów układów HPCR, a ich skład chemiczny jest zupełnie odmienny od wyżej opisanych mydeł z jonem metalicznym. Osady te nie zawierają w swym składzie jonów metalicznych. Powstają na skutek reakcji powszechnie stosowanych dodatków detergentowych do olejów napędowych w postaci poliizobutylenowego imidu kwasu bursztynowego (PIBSI - polyisobutylene succinimide), przeciwdziałającego powstawaniu zewnętrznych osadów koksowych, z kwasem mrówkowym, inhibitorami korozji lub dodatkami smarnościowymi stanowiącymi monomery bądź dimery kwasów tłuszczowych. Szczególnie podatne na tworzenie przedmiotowych osadów są PIBSI $\mathrm{z}$ dużą zawartością aminy pierwszorzędowej $\mathrm{w}$ interakcji z dimerami karboksylowych kwasów tłuszczowych. Powstałe osady są nierozpuszczalne w ogólnie stosowanych rozpuszczalnikach organicznych, co bardzo utrudnia ich analizę i określenie budowy chemicznej.

Dotychczas przeprowadzone badania wskazują też na możliwość powstawania IDID z produktów utleniania paliw. Produkty takie mogą występować zwłaszcza w przypadku niestabilnych olejów napędowych zawierających FAME lub pochodzić ze starzenia estrowych kwasów thuszczowych wstępujących $\mathrm{w}$ dodatkach smarnościowych $[1-5$, 7-9, 11].

Podsumowując, wyżej opisane IDID, występujące w układach wtrysku paliwa HPCR, można podzielić na trzy typy:

Typ I - określane są jako: mydła zawierające jon metaliczny (w większości sodowe mydła kwasów tłuszczowych) lub osady „woskowe”, albo mydła karboksylowe, albo też sole karboksylowe. Powstają one na skutek współdziałania: - inhibitorów korozji z monomerami kwasów tłusz- 
Type III - defined as: fuel oxidation products. Those result from deterioration of FAME contained in diesel fuel and/ or are products of deterioration of fatty acids originating from lubricating additives.

\section{Assumptions concerning research conducting}

The aim of the research was to produce IDID in specially developed engine tests creating favourable conditions for this type deposits formation and defining the influence of the subject deposits on the key operational parameters of fuel injection system of HPCR type.

The tests were conducted with the use of universal engine test stand constructed in INiG. The essential element of the test stand was a modern diesel engine of HSDI type of FORD make, identified as 2.0i 16V Duratorq TDCi. The engine was powered by direct, high-pressure fuel injection system of HPCR type.

As it has been proved in tests conducted so far, high temperature of fuel flowing through HPCR system promotes IDID formation. During engine operation, fuel excessively supplied to injectors continuously cools them (its larger part is drained back to fuel tank with the use of overflow ducts), but as the engine stops, in the initial stage of its cooling, the tips of injectors are exposed to even higher temperatures. Making that assumption and taking into consideration the fact that the engine on the test stand cannot operate continuously due to specificity of the engine test bed, it was proposed that the test should be conducted with intervals varying in length (which is, by the way, consistent with the way of exploiting vehicles, which are also not exploited continuously), and intervals between subsequent engine starts should differ in length. As a result it was established that the most propitious conditions for IDID formation would be created for engine operating with fixed parameters during the whole period of test, i.e. for engine speed of $3000 \mathrm{rpm}$ and load of $160 \mathrm{Nm}$, which is equivalent to temperature measured directly close to injector tip, ranging from 365 to $380{ }^{\circ} \mathrm{C}$ (depending on the cylinder in which the measurements are taken). In such conditions of the test the temperature of fuel in overflow ducts of injectors amounted to $95-115^{\circ} \mathrm{C}$. It was assumed that in the test the engine would be started in cycles for two hours, then it would be turned off for 2 to 16 hours, followed by subsequent two hours of operation and turning off and so on, until 60 hours of actual engine operation would be achieved (e.i. 30 cycles, each two hours long). The test was to be finished earlier in case of injector dysfunction precluding start and further operation of the engine. For each test was used a new set of injectors after initial diagnostic assessment in authorized service centre. While operating, the engine parameters would be kept on fixed levels as far as engine speed and delivery rate of injection pump are considered, and the following parameters would be monitored: engine speed, engine power and torque, exhaust gas temperature in exhaust system, fuel consumption and exhaust gas opacity.

The engine was fueled with commercial diesel oil EKODIESEL ULTRA F 4.8 with addition of mixture of chemical compounds dissolved in diesel fuel (prepared in form of 1-litre premixes) which, as results of previously czowych wykorzystywanych w dodatkach smarnościowych,

- inhibitorów korozji z dimerami kwasów tłuszczowych wykorzystywanych w dodatkach smarnościowych, - inhibitorów korozji z kwasami alkenylo-bursztynowymi jak DDS (dodecenyl succinic acid) i HDS (hexadecenyl succinic acid) wykorzystywanych w dodatkach smarnościowych.

Typ II - określane są jako: lepkie, lakowe osady lub osady polimerowo-organiczne, albo osady amidowe. Powstają one na skutek współdziałania:

- dodatków detergentowych w postaci poliizobutylenowego imidu kwasu bursztynowego (PIBSI - polyisobutylene succinimide) z kwasem mrówkowym,

- dodatków detergentowych jak PIBSI z kwasem tłuszczowym wykorzystywanym w dodatkach smarnościowych (w szczególności z dimerów kwasów tłuszczowych).

Typ III - określane są jako: produkty utleniania paliwa. Powstają na skutek starzenia FAME zawartego w ON i/lub jako produkty starzenia kwasów tłuszczowych pochodzących z dodatków smarnościowych.

\section{Zalożenia dotyczące prowadzenia badań}

Celem badań było wytworzenia IDID w warunkach specjalnie opracowanych testów silnikowych, sprzyjających powstawaniu tego typu osadów, oraz określenie wpływu przedmiotowych osadów na kluczowe parametry pracy układu wtrysku paliwa typu HPCR.

Badania przeprowadzono przy wykorzystaniu uniwersalnego, silnikowego stanowiska badawczo-testowego skonstruowanego w INiG. Zasadniczym elementem stanowiska jest nowoczesny silnik wysokoprężny typu HSDI marki FORD, noszący oznaczenie 2.0i 16V Duratorq TDCi. Silnik jest zasilany wysokociśnieniowym układem wtrysku paliwa typu HPCR.

Jak stwierdzono w dotychczasowych badaniach, wysoka temperatura paliwa przepływającego przez HPCR sprzyja tworzeniu IDID. Podczas pracy silnika podawane do wtryskiwaczy z dużym nadmiarem paliwo stale je chłodzi (jego większa część jest odprowadzana za pomocą przelewów z powrotem do zbiornika paliwa), natomiast po zatrzymaniu silnika powstają, w początkowym okresie jego chłodzenia, warunki jeszcze większego nagrzania końcówek wtryskiwaczy. Wychodząc z tego założenia i biorąc pod uwagę, że silnik na stanowisku badawczym nie będzie mógł być eksploatowany bez przerwy, co wynika ze specyfiki pracy hamowni, założono, że test będzie prowadzony z przerwami o różnej długości. Jest to zgodne ze sposobem eksploatacji pojazdów, które też nie są używane bez przerwy, a czasowe przerwy pomiędzy kolejnymi uruchomieniami silnika są różne. W konsekwencji ustalono, że najbardziej sprzyjające warunki do powstawania osadów typu IDID będą stworzone podczas pracy silnika na stałych parametrach przez całych czas prowadzenia testu, tj. przy prędkości obrotowej $3000 \mathrm{obr} / \mathrm{min}$ i obciążeniu $160 \mathrm{Nm}$, co odpowiada temperaturze zmierzonej w bezpośredniej bliskości końcówki wtryskiwacza, w granicach $365-380^{\circ} \mathrm{C}$ (w zależności od cylindra, w którym prowadzono pomiary). $\mathrm{W}$ tych warunkach prowa- 
conducted tests in different laboratories worldwide suggest, have the biggest influence on initialisation and formation of IDID [1, 6-9, 11, 12].

Below is described the first batch of mixture aiming at formation of IDID of the I type, i.e. soaps containing metal ion.

Two batches of additive were prepared, each for 3001 of fuel, with assumed dosage of active substances of $150 \mathrm{mg} / \mathrm{kg}$. Single batch was formed from $37.5 \mathrm{~g}$ of dodecenyl succinic acid, $7.5 \mathrm{~g}$ of sodium nitrite (weight ratio $5: 1$ ) and $50.0 \mathrm{~g}$ of Shellsol A. The mixture was homogenized by heating up to $40{ }^{\circ} \mathrm{C}$ and ultrasonic treatment for about 1 hour. Sodium nitrite reacted while mixing with acid in ultrasonic bath, releasing nitric oxides. The product obtained was practically solution of sodium salt of dodecenyl succinic acid (soap) saturated with nitric oxides. From that batch a premix was prepared by diluting with fuel up to a volume of $1 \mathrm{dm}^{3}$.

The second batch of substance mixture, aiming at formation IDID of the second type, i.e. viscous, waxy organic polymer deposits, was prepared as described below.

Two batches of additive were prepared, each for 3001 of fuel, with assumed dosage of active substances of $200 \mathrm{mg} / \mathrm{kg}$. Single batch included $46.7 \mathrm{~g}$ of succinic acid imide containing free primary amine groups and $13.3 \mathrm{~g}$ of neodecanoic acid (weight ratio 3:1) and $50.0 \mathrm{~g}$ of Shellsol A. The mixture was homogenized by heating up to $40^{\circ} \mathrm{C}$ and ultrasonic treatment for about 1 hour. From that batch a premix was prepared by diluting with fuel up to a volume of $1 \mathrm{dm}^{3}$.

\section{Results of engine tests}

In the first simulation engine test the influence of diesel oil containing the first batch of the above-described premix on IDID formation was assessed. During the test were observed essential, and increasing with testing time, irregular changes (fluctuations) within the measured engine parameters, i.e. engine torque, power, exhaust gas temperature and amount of exhaust gas opacity. It was determined that those changes ensued from gradual formation of deposits on internal surfaces of working elements of injectors. It caused disturbances in dynamic of operation and in the intervals when engine was stopped, also sticking together of elements responsible for regulation of fuel flow and dosage, leading to at least temporary immobilization of control piston of electromagnetic valve and/or needle controlling opening and closing of injectors. In consequence, if we assume that the injector needle got stuck (glued) in the open position of the injector or that the injector closing time was significantly slowed down (extended) due to difficulty in shifting the needle because of deposits settled on working surfaces, it led to increase of the maximum fuel dose exceeding the dose foreseen by the engine manufacturer. It resulted in increase of power above that normally gained for given rate of delivery of the injection pump. On the other hand, assuming immobilization of control piston of the electromagnetic valve in position restricting supply of required amount of fuel to the duct before nozzle injection holes or jamming the nozzle needle in position of partially closed injector, deficiency of fuel would result in uncontrolled reduction of engine power. Of course, the above-mentioned phenomena might differ in intensity for injectors in different dzenia testu, temperatura paliwa w przewodach przelewowych wtryskiwaczy wynosiła $95-115^{\circ} \mathrm{C}$. Przyjęto, że w teście silnik uruchamiany jest cyklicznie, na dwie godziny, po czym zostaje wyłączony na okres 2 do 16 godzin, następnie zostaje uruchomiony na kolejne dwie godziny, potem wyłączony itd., aż do osiągnięcia 60 godzin rzeczywistej pracy silnika (tj. 30 cykli po 2 godziny). Test może być zakończony wcześniej wtedy, gdy powstaną dysfunkcje wtryskiwaczy uniemożliwiające uruchomienie i dalszą pracę silnika. Do każdego testu stosowany jest nowy komplet wtryskiwaczy po przeprowadzeniu jego wstępnej, diagnostycznej oceny w autoryzowanym serwisie. W czasie pracy silnika jego parametry utrzymywane są na stałym poziomie w zakresie wielkości wydatku pompy wtryskowej i prędkości obrotowej, a monitorowaniu podlegają następujące parametry: prędkość obrotowa, moc i moment obrotowy silnika, temperatura spalin w układzie wylotowym, wielkość zużycia paliwa i wielkość zadymienia spalin.

Do zasilania silnika używano handlowego oleju napędowego EKODIESEL ULTRA F 4,8, do którego dodawano (przygotowane w postaci 1-litrowych przedmieszek) mieszaniny związków chemicznych rozpuszczonych w przedmiotowym ON, które, jak sugerują dostępne wyniki dotychczas przeprowadzonych badań w różnych laboratoriach na świecie, mają największy wpływ na zainicjowanie i tworzenie IDID [1, 6-9, 11, 12].

Poniżej opisano pierwszy pakiet mieszaniny substancji, mających doprowadzić do wytworzenia pierwszego typu IDID, tzn. mydeł zawierających jon metaliczny.

Przygotowano dwie partie dodatku, każda na 3001 paliwa, przy założeniu dozowania substancji aktywnych na poziomie $150 \mathrm{mg} / \mathrm{kg}$. Pojedyncza partia zestawiona została z 37,5 g kwasu dodecylobursztynowego i 7,5 g azotynu sodu (stosunek wagowy 5:1) oraz 50,0 g Shellsolu A. Mieszaninę ujednorodniono przez ogrzanie do temperatury $40{ }^{\circ} \mathrm{C}$ i poddanie działaniu ultradźwięków przez ok. 1 godz. Azotyn sodu w czasie mieszania z kwasem w łaźni ultradźwiękowej reagował z wydzieleniem tlenków azotu. Otrzymany produkt był praktycznie roztworem soli sodowej kwasu dodecylobursztynowego (mydło) nasyconym tlenkami azotu. $\mathrm{Z}$ tak otrzymanego pakietu sporządzono przedmieszkę przez rozcieńczenie paliwem do objętości $1 \mathrm{dm}^{3}$.

$\mathrm{Z}$ kolei drugi pakiet mieszaniny substancji, mających doprowadzić do wytworzenia drugiego typu IDID, tzn. zawierających lepkie, lakowe osady polimerowo organiczne wykonano następująco: przygotowano dwie partie dodatku, każda na 3001 paliwa, przy założeniu dozowania substancji aktywnych na poziomie $200 \mathrm{mg} / \mathrm{kg}$. Pojedyncza partia zestawiona została z 46,7 g imidu kwasu bursztynowego zawierającego wolne I-rzędowe grupy aminowe i 13,3 g kwasu neodekanowego (stosunek wagowy 3:1) oraz 50,0 g Shellsolu A. Mieszaninę ujednorodniono przez ogrzanie do temperatury $40{ }^{\circ} \mathrm{C}$ i poddanie działaniu ultradźwięków przez ok. 1 godz. Z tak otrzymanego pakietu sporządzono przedmieszkę przez rozcieńczenie paliwem do objętości $1 \mathrm{dm}^{3}$. 
engine cylinders, nevertheless they disturb the run of power, torque, engine exhaust gas temperature and other parameters, through uncontrolled quantity (excess air number $\lambda$ ) and quality changes in prepared combustible mixture.

a)

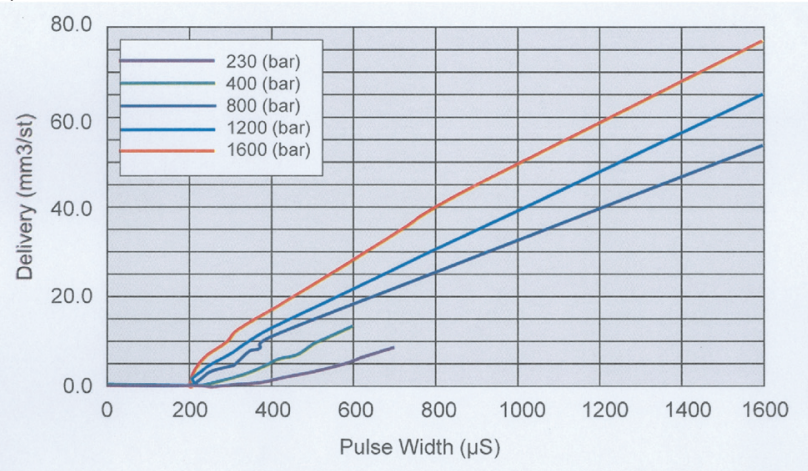

b)

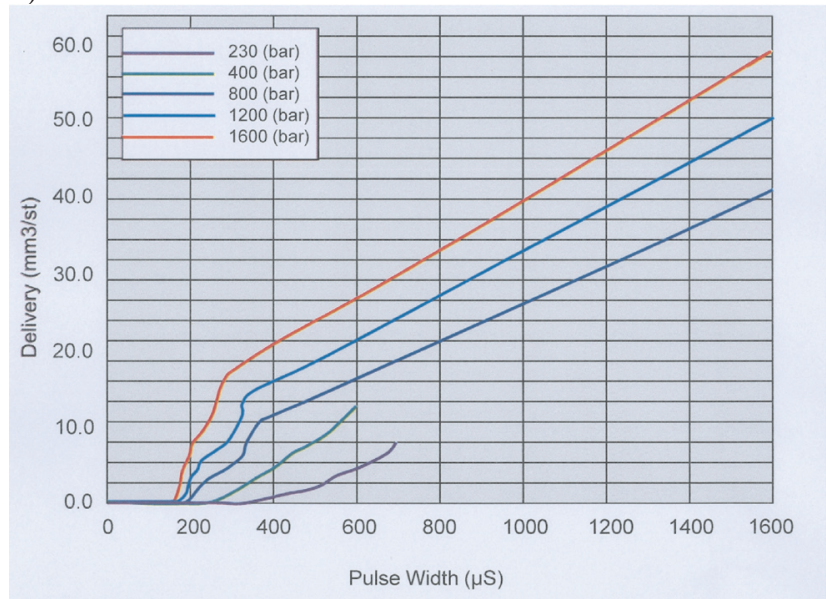

Fig. 2. Comparison of dosing characteristics for one injector before (a) and after (b) first engine test

Rys. 2. Porównanie charakterystyk dawkowania jednego z wtryskiwaczy przed (a) i po przeprowadzonym (b) pierwszym teście silnikowym

After the test was completed, the injectors were subjected to diagnostic assessment in authorized diagnostic, adjustment and repair service for fuel injection systems. The assessment confirmed the above described observations and hypothesis. For each assessed injector after the engine test there was observed a significant decrease in the amount of dosed fuel (axis of ordinates) in relation to given width of electric impulse (axis of abscissas) determining the time of injector opening independent of assumed pressure. Within the range from about $200 \mu$ s to $400 \mu$ s of impulse duration (start of injection) there were explicitly confirmed time and quantity disturbances in fuel dose stabilization ensuing from the changes (deterioration) of operating dynamic of internal working elements of injector responsible for overflow fuel flow control and fuel injection. Therefore, there is no doubt that deposits of IDID type generated in injectors have unequivocally negative influence on injector's operation. In Figure 2 is presented as an example comparison of characteristics of fuel dosing before and after conducted tests.

\section{Wyniki testów silnikowych}

W pierwszym, symulacyjnym teście silnikowym oceniany był wpływ oleju napędowego zawierającego pierwszy pakiet wcześniej opisanych substancji na tworzenie IDID. Podczas testu obserwowano istotne, zwiększające się w miarę upływu czasu testu, nieregularne zmiany (wahania) $\mathrm{w}$ zakresie mierzonych parametrów pracy silnika, tj.: momentu obrotowego, mocy, temperatury spalin i wielkości zadymienia spalin. Jak ustalono, zmiany te były wynikiem stopniowego tworzenia się osadów na powierzchniach wewnętrznych, roboczych elementów wtryskiwaczy. Powodowało to zaburzenia dynamiki ich pracy, a w czasie przerw w pracy silnika sklejanie elementów odpowiedzialnych za regulację przepływu paliwa i jego dozowanie, skutkujące co najmniej czasowym unieruchomieniem tłoczka sterującego zaworu elektromagnetycznego i/lub iglicy sterującej otwieraniem i zamykaniem wtryskiwacza. W konsekwencji, jeśli założymy, że iglica wtryskiwacza zawiesiła (skleiła) się w pozycji otwarcia wtryskiwacza lub czas zamykania wtryskiwacza został znacznie wydłużony na skutek utrudnionego przesuwu iglicy przez powstałe na powierzchniach roboczych IDID, prowadziło to do zwiększenia maksymalnej dawki paliwa powyżej zakładanej przez producenta silnika. Skutkowało to wzrostem mocy powyżej normalnie uzyskiwanej dla danego wydatku pompy wtryskowej. Z kolei, gdyby założyć unieruchomienie tłoczka sterującego zaworu elektromagnetycznego w pozycji ograniczającej dopływ wymaganej ilości paliwa do kanalika przed otworkami wtryskowymi rozpylacza lub zakleszczenie iglicy rozpylacza w pozycji częściowo zamkniętego wtryskiwacza, niedobór paliwa będzie wpływał na niekontrolowane zmniejszenie mocy silnika. Oczywiście wyżej opisane zjawiska mogą przebiegać z różną intensywnością we wtryskiwaczach poszczególnych cylindrów silnika, tym niemniej będą one zaburzały płynny przebieg zmian mocy, momentu obrotowego, temperatury spalin silnika i innych, przez niekontrolowane zmiany ilościowe (współczynnika nadmiaru powietrza $\lambda$ ) i jakościowe mieszanki palnej.

Po zakończeniu testu wtryskiwacze były przekazywane do oceny diagnostycznej w autoryzowanej stacji kontroli, regulacji i naprawy układów wtryskowych. Potwierdziły ona wyżej opisane obserwacje i hipotezy. Dla każdego z ocenianych wtryskiwaczy, po teście silnikowym nastąpił znaczący spadek wielkości dawki dozowanego paliwa (oś rzędnych) w odniesieniu do określonej szerokości impulsu elektrycznego (oś odciętych) decydującego o czasie otwarcia wtryskiwacza, niezależnie od założonego ciśnienia. W zakresie czasu impulsu od około $200 \mu$ s do $400 \mu \mathrm{s}$ (początek wtrysku), jednoznacznie stwierdzono czasowe i ilościowe zaburzenia w stabilizowaniu się dawki paliwa, będące następstwem zmian (pogarszania się) dynamiki pracy wewnętrznych elementów roboczych wtryskiwacza odpowiedzialnych za sterowanie przepływem paliwa nadmiarowego i sam wtrysk paliwa. Zatem nie ulega wątpliwości, że wytworzone we wtryskiwaczach osady typu IDID miały jednoznacznie negatywny wpływ na ich funkcjonowanie. Na rysunku 2 przedstawiono przykładowe 
Disassembly of injectors after conducted test revealed deposits settling on surfaces of internal elements of injectors washed by fuel - Fig. 3. Deposits were of light grey colour, in case of thicker layers (of $1-1.5 \mu \mathrm{m}$ ) their surface was cracked and they revealed tendency to scaling and crumbling. While shifting the needle in nozzle casing there was expressly felt resistance and roughness of cooperating surfaces. Similarly movement of control piston of electromagnetic valve was difficult. Taking into account high precision and narrow manufacturing tolerances for injector elements, the generated deposits of very small thickness led to disturbances in injector operation excluding it from further safe operation in real operating conditions.

During the second engine test (fuel contained the second batch of substances potentially generating IDID) were found even more significant changes (fluctuations) of the key parameters, i.e. torque, power, engine temperature and ex-

a)

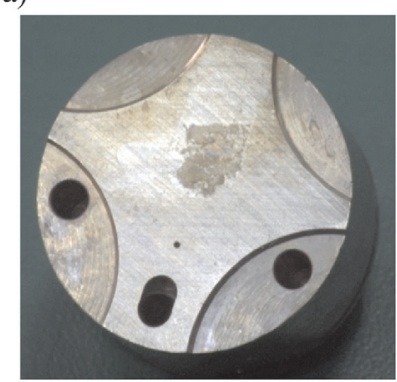

b)
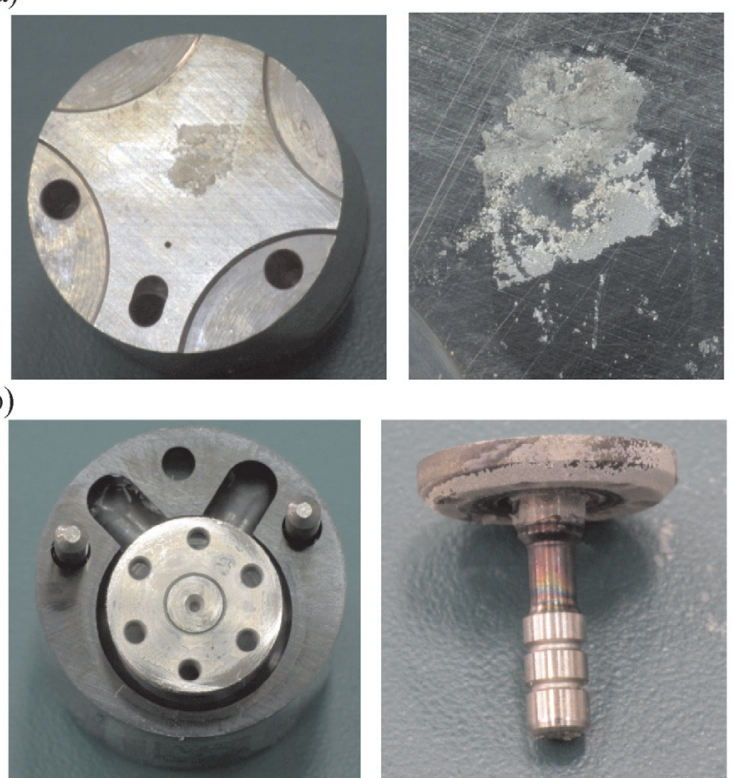

b)

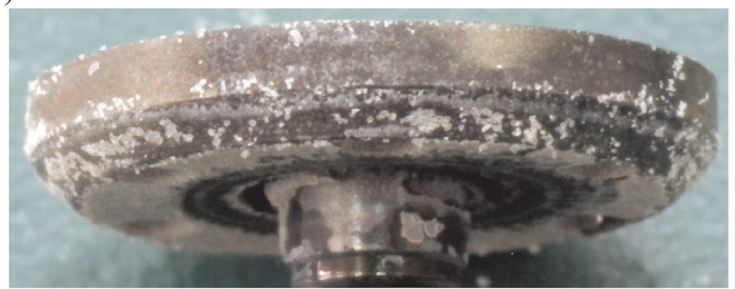

c)

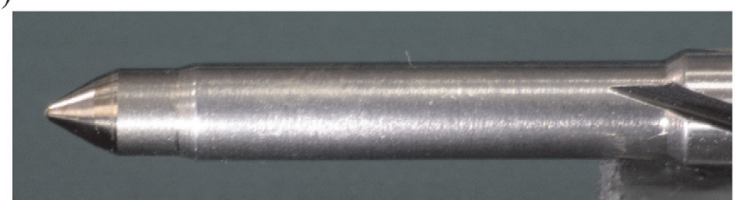

Fig. 3. Deposits (type I) on internal elements of injectors of HPCR system: a) body of chamber controlling fuel flow, b) body of control valve and control piston of electromagnetic valve, c) nozzle needle

Rys. 3. Osady (Typ I) na wewnętrznych elementach wtryskiwaczy układu HPCR: a) korpus komory sterujacej przeptywem paliwa, b) korpus

zaworu sterujacego i tloczek sterujacego zaworu elektromagnetycznego, c) iglica rozpylacza porównanie charakterystyk dawkowania przed i po przeprowadzonym teście.

Demontaż wtryskiwaczy, po przeprowadzonej próbie, ujawnił osady, jakie powstały na omywanych przez paliwo powierzchniach wewnętrznych elementów wtryskiwacza rys. 3. Osady miały biało-szare zabarwienie, w przypadku grubszych warstw (rzędu 1-1,5 $\mu \mathrm{m}$ ) ich powierzchnia była popękana, a ponadto wykazywały tendencje do łuszczenia się i wykruszania. Podczas przesuwania iglicy w korpusie rozpylacza wyczuwalne były wyraźne opory i szorstkość współpracujących powierzchni. Podobnie poruszanie się tłoczka sterującego zaworu elektromagnetycznego było utrudnione. Biorąc pod uwagę duże dokładności i małe tolerancje wykonawcze elementów wtryskiwaczy, wytworzone osady o bardzo małej grubości doprowadziły do zaburzeń w pracy wtryskiwaczy, które wykluczały możliwość ich dalszego, bezpiecznego stosowania w warunkach rzeczywistej eksploatacji.

Podczas prowadzenia drugiego testu silnikowego (paliwo zawierało drugi pakiet substancji podejrzewanych o tworzenie IDID) stwierdzono jeszcze większe zmiany (wahania) kluczowych parametrów pracy silnika, tj.: momentu obrotowego, mocy, temperatury spalin i wielkości zadymienia spalin niż dla testu pierwszego. Pod koniec testu obserwowano znaczny spadek mocy i momentu obrotowego silnika będący wynikiem, jak się potem okazało (po rozmontowaniu jednego z wtryskiwaczy), całkowitego sklejenia się iglicy z korpusem rozpylacza. Należy tu jeszcze raz podkreślić, że już bardzo cienka, rzędu 0,4-0,5 $\mu \mathrm{m}$ (niekiedy trudna do fotograficznego zarejestrowania metodami konwencjonalnej fotografii), warstwa osadów typu IDID może doprowadzić do dysfunkcji wtryskiwacza nie tylko utrudniającej, ale nawet uniemożliwiającej jego funkcjonowanie. Podczas tego testu obserwowano też znaczne różnice w zakresie monitorowanej wielkości zadymienia spalin, co potwierdza duże zaburzenia w zakresie jakościowego i ilościowego tworzenia mieszanki palnej w komorach silnika. Pozostałe obserwacje i hipotezy były analogiczne do tych wysuniętych i opisanych podczas prowadzenia pierwszego testu.

Wyniki porównawczej oceny diagnostycznej wtryskiwaczy przed i po przeprowadzonym teście silnikowym były podobne do tych po teście pierwszym. Dla każdego z ocenianych wtryskiwaczy nastąpił znaczący spadek wielkości dawki dozowanego paliwa (oś rzędnych) w odniesieniu do określonej szerokości impulsu elektrycznego (oś odciętych) decydującego o czasie otwarcia wtryskiwacza, niezależnie od wielkości ciśnienia podawanego paliwa. Wyniki oceny w postaci porównania charakterystyk dawkowania paliwa dla jednego (przykładowego) wtryskiwacza przed i po teście przedstawiono na rys. 4 . W zakresie czasu impulsu od około $200 \mu \mathrm{s}$ do $400 \mu$ s (początek wtrysku) widać wyraźnie czasowe i ilościowe zaburzenia w stabilizowaniu się dawki paliwa, będące następstwem zmian (pogarszania się) dynamiki pracy wewnętrznych elementów roboczych wtryskiwacza odpowiedzialnych za sterowanie przepływem paliwa nadmiarowego i sam wtrysk paliwa. 
haust gas opacity, than in the first test. At the end of test was observed significant decrease of power and torque of engine that resulted, as later was discovered (after disassembling of one of injectors), from sticking together of the needle with body of the nozzle. It should be pointed out once more that even very thin layer of deposits of IDID type, from 0.4 to $0.5 \mu \mathrm{m}$ thick (sometimes difficult to record with conventional photography methods), may lead to injector dysfunction not only making its operation difficult but even totally impossible. During the test were observed significant differences within monitored opacity of exhaust fumes, which confirms significant disturbances as far as quality and quantity of combustible mixture preparation in engine chambers is concerned. Other observations and hypothesis were analogical to those put forward and described for the first test.

The results of comparative diagnostic assessment of injectors before and after conducted engine test were similar to those in the first test. For each assessed injector was observed significant decrease in the amount of dosed fuel (axis of ordinates) in relation to a given width of electric impulse (axis of abscissas) determining time of opening of injector independent of the pressure of supplied fuel. The comparative results of characteristics of fuel dosing for one (demonstration) injector before and after the test are presented in Fig. 4.

Within the range from about $200 \mu$ s to $400 \mu$ s of impulse time (start of injection) might be expressly observed time and quantity disturbances in fuel dose stabilization ensuing from the changes (deterioration) of operating dynamic of the internal working elements of injector responsible for overflow fuel flow control and fuel injection.

Disassembling one of the injectors it was found that the needle got stuck within the nozzle body and there was observed significant difficulty in movement of plunger, a control piston of electromagnetic valve in cylinder. Deposits formed on internal elements of injectors were of wax type in dark yellow and brow colour - Fig. 5 . Thus, visually they were completely different from deposits forming during the first test. Confirmed tendency for fast and quite permanent sticking of working elements of injectors together allows to make an assumption that deposits formed in the second test were rather viscous than scuffing as were the deposits from the first test.

\section{Conclusions}

The problem of damages to fuel injection systems of HPCR type caused by internal deposits (IDID) generated inside injectors is becoming more significant globally while our knowledge of the mechanisms of their formation and deposits composition is still insufficient and needs further research works.

There is no doubt that deposits of IDID type generated in injectors during conducted engine tests had unequivocally negative influence on functioning of fuel injector system and in consequence caused deterioration of operational characteristics of engine.

Despite very small thickness of IDID deposits (typically of about 0.5 to $1.5 \mu \mathrm{m}$ ), they can lead to disturbances or complete dysfunction of injectors, especially of those of HPCR system. It ensues, among the others, from high precision of manufacturing of the key operational elements of injectors
Rozmontowując jeden z wtryskiwaczy, po zakończonym teście, stwierdzono, jak już wspominano, sklejenie iglicy z korpusem rozpylacza oraz znaczne utrudnienia ruchu nurnika tłoczka sterującego zaworu elektromagnetycznego w cylinderku. Powstałe na powierzchniach wewnętrznych elementów wtryskiwaczy osady były koloru miodowo-brązowego i miały charakter laków - rys. 5 . Zatem były one wizualnie zupełnie odmienne od tych, jakie obserwowano podczas pierwszego testu. Stwierdzona tendencja do szybkiego i dość trwałego sklejania elementów roboczych wtryskiwaczy pozwala przypuszczać, że wytworzone w drugim teście osady były bardziej lepkie, a nie zacierające, jak te powstałe w pierwszym teście.

a)

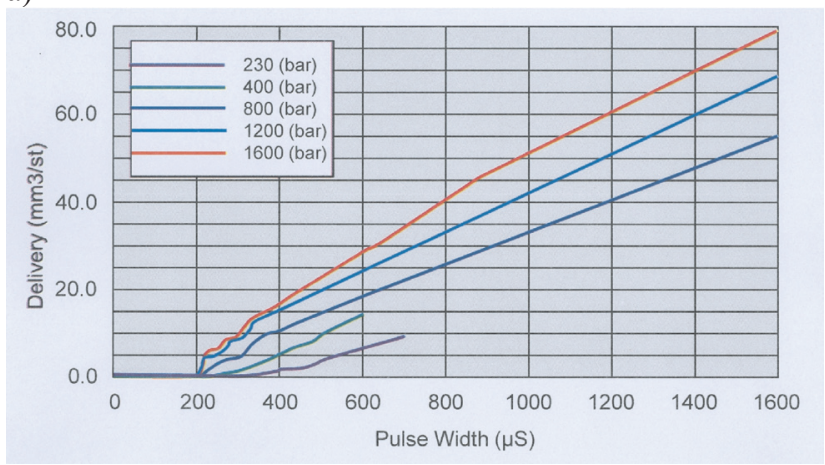

b)

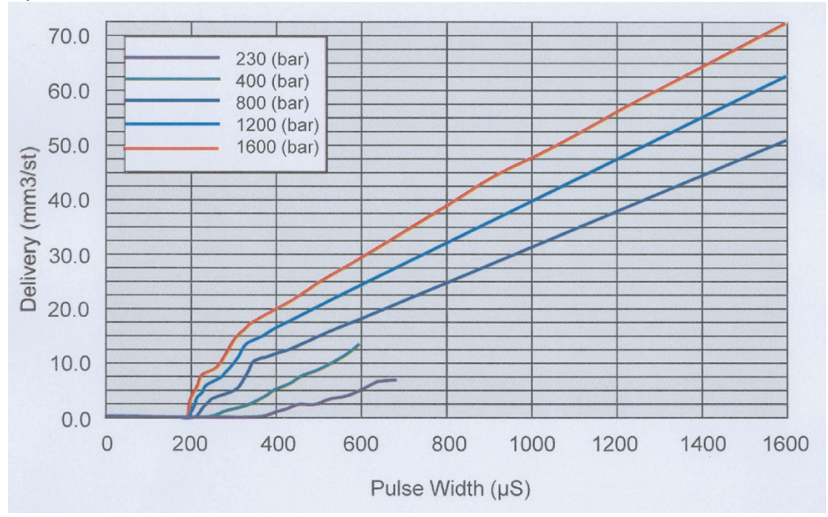

Fig. 4. Comparison of characteristics of dosage of one injector before (a) and after (b) the second engine test conducted

Rys. 4. Porównanie charakterystyk dawkowania jednego z wtryskiwaczy przed (a) i po (b) przeprowadzony drugim teście silnikowym

\section{Wnioski}

Problem uszkodzeń układów wtrysku paliwa typu HPCR przez tworzące się w nich osady wewnętrzne (IDID) nabiera coraz większego, globalnego znaczenia, natomiast wiedza dotycząca mechanizmów ich powstawania oraz składu jest w dalszym ciągu niewystarczająca i wymaga prowadzenia dalszych badań poznawczych.

Nie ulega wątpliwości, że wytworzone we wtryskiwaczach, w ramach przeprowadzonych testów silnikowych, osady typu IDID miały jednoznacznie negatywny wpływ na funkcjonowanie układu wtrysku paliwa i w konsekwencji pogorszenie właściwości użytkowo-eksploatacyjnych silnika

Pomimo bardzo małej grubości osadów typu IDID 
and intense dynamic of operation of the moving working elements that makes them prone and sensitive to influence from this type of deposits.

a)

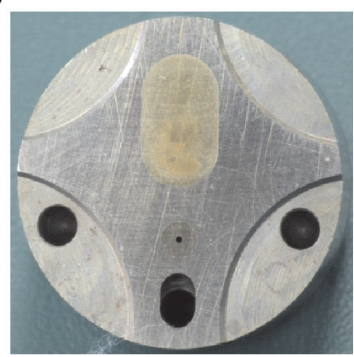

b)
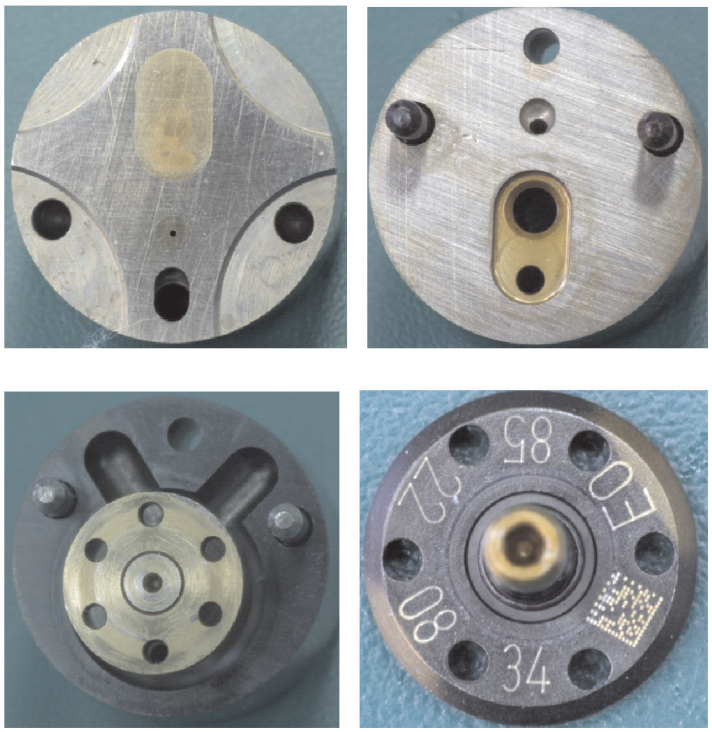

b)

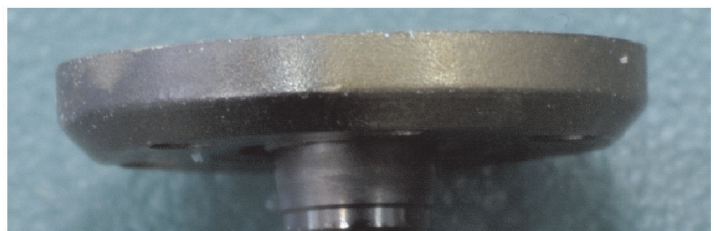

c)

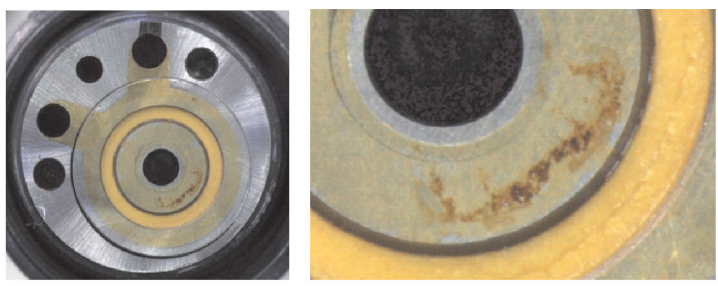

d)

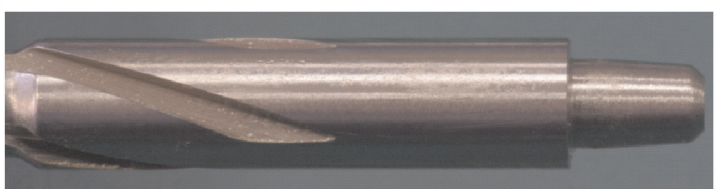

Fig. 5. Deposits (Type II) on internal elements of injectors of HPCR system: a) body of chamber controlling fuel flow and body of control valve, b) body of control valve chamber and piston of control electromagnetic valve, c) controlling electromagnetic coil, d) nozzle needle

Rys. 5. Osady (Typ II) na wewnętrznych elementach wtryskiwaczy uktadu HPCR: a) korpus komory sterujacej przeptywem paliwa i korpus zaworu sterujacego, b) korpus komory zaworu sterujacego $i$ tloczek sterujacego zaworu elektromagnetycznego, c) elektromagnes sterujacy, d) iglica rozpylacza

Zbigniew Stępień, DEng.- doctor in Oil and Gas Institute in Krakow.

Dr inż. Zbigniew Stępień - adiunkt w Instytucie Nafty i Gazu w Krakowie. email: stepien@inig.pl (zazwyczaj około 0,5 do 1,5 $\mu \mathrm{m}$ ), mogą one prowadzić do zaburzeń lub całkowitej dysfunkcji zwłaszcza wtryskiwaczy układów HPCR. Wynika to, między innymi, z niezwykle dużej precyzji wykonania kluczowych elementów funkcjonalnych wtryskiwaczy oraz bardzo dużej dynamiki pracy ich ruchomych elementów roboczych, co czyni je bardzo wrażliwymi i podatnymi na oddziaływanie tego typu osadów.

\section{Abbreviations/Wykaz skrótów}

DDS dodecenyl succinic acid/kwas dodecenylobursztynowy

FAME Fatty Acid Methyl Esters/estry metylowe kwasów tluszczowych

HDS hexadecenyl succinicacid/kwas heksade cennylobursztynowy

HPCR High Pressure Common Rail/wysokociśnieniowy układ wtryskowy Common Rail

HSDI High Speed Direct Injection/wtrysk bezpośredni

IDID Internal Diesel Injector Deposits/osady wewnętrzne we wtryskiwaczach silników ZS

PIBSI polyisobutylene succinimide/imid poliizobutylenobursztynowy

\section{Bibliography/Literatura}

[1] Quigeley R., Barbour R., Fahey E., Arters D., Wetzel W., Ray J.: A Study of The Internal Diesel Injector Deposit Phenomenon; TAE Fuels 7th Annual Colloquium, January 2009.

[2] Chapman L.: Diesel Soap - Formation and Related Problems; National Tanks Conference, Boston, MA September 21, 2010.

[3] CEN/TC 19/WG 24: Report of the Ad-hoc Injector Sticking Task Force - 02 August 2011.

[4] Ullmann J., Gedulding M., Stutzenberger H., Caprotti R., Balfour G.: Effects of Fuel Impuerities and Additive Interactions on the Formation of Internal Diesel Injector Deposits; TAE Fuels 8th Annual Colloquium, January - 2011.

[5] Ullmann J., Gedulding M., Stutzenberger H., Caprotti R., Balfour G.: Investigation into the Formation and Prevention of Internal Diesel Injector Deposits; SAE Technical Paper No 2008-01-0926.

[6] Caprotti R., Breakspear A., Klaua T., Weiland P., Graupner O., Bittner M.: RME Behaviour in Current and Future Diesel Fuel FIE's; SAE Technical Paper No 2007-01-3982.

[7] Caprotti R., Bhatti N., Balfour G.: Deposit Control in Modern Diesel Fuel Injection Systems; SAE Technical Paper No 201001-2250.

[8] Caprotti R., Breakspear A., Graupner O., Klaua T., Kohnen O.: Diesel Injector Deposits Potential In Future Fueling Systems; SAE Technical Paper No. 2006-01-3359.

[9] Barker J., Richards P., Goodwin M., Wooler J.: Influence of High Injection Pressure on Diesel Fuel Stability: A Study of Resultant Deposits; SAE Technical Paper No 2009-01-1877.

[10] Graupner O., Klaua T., Caprotti R., Schik A.: Injector Deposit Test For Modern Diesel Engines; APL Automobil Prueftechnik Landau Gmh. TAE Symposium, 2005.

[11] Ullmann J., Stutzenberger H.: Internal Diesel Injector Deposit Formation - Reproduction in Laboratoey, System Bench and Engine Tests; 9th International Colloquium Fuels - Esslingen 15 - 17 January 2013.

[12] Barbour R., Quigley R., Panesar A., Payne J., Arters D., Bush J., Stevens A.: Finding a Solution to Internal Diesel Injector Deposits; 9th International Colloquium Fuels - Esslingen 15 - 17 January 2013. 